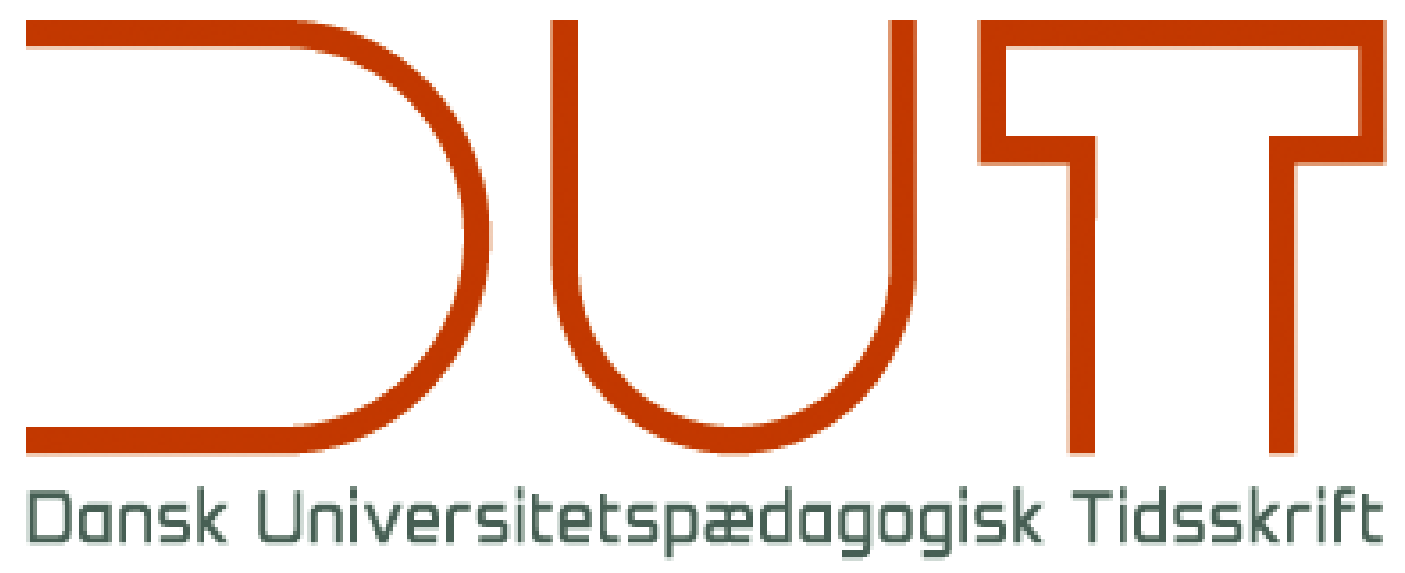

Undervisningens teknologier og teknikker

Årgang 15 nr. 28 / 2020

Titel

Forfattere

Sidetal

Udgivet af

URL

Studerendes forventninger til specialevejledning og specialevejledere

- en surveyundersøgelse

Jacob Thøgersen, Anita Dybdal

$182-209$

Dansk Universitetspædagogisk Netværk, DUN

> http://dun-net.dk/

Betingelser for brug af denne artikel

(c) Copyright
Denne artikel er omfattet af ophavsretsloven, og der må citeres fra den. Følgende betingelser skal dog være opfyldt:

- Citatet skal være i overensstemmelse med "god skik“

- Der må kun citeres „i det omfang, som betinges af formålet"

- Ophavsmanden til teksten skal krediteres, og kilden skal angives ift. ovenstående bibliografiske oplysninger.

DUT og artiklens forfatter 


\title{
Studerendes forventninger til specialevejledning og specialevejledere - en surveyundersøgelse
}

\author{
Jakob Thøgersen ${ }^{a, 1}$, Anita Dybdal Kristiansen ${ }^{b}$ \\ anstitut for Nordiske Studier og Sprogvidenskab, Københavns Universitet \\ bJobcenter København, Center for Kompetence og Brobygning
}

Videnskabelig artikel, fagfællebedømt

\begin{abstract}
Ved hjælp af et spørgeskema undersøger vi forventninger til specialeprocessen, arbejdsindsats og resultater samt forventninger til deres vejleder og deres relation til denne blandt en årgang af nystartede specialeskrivere på et humanistisk institut.

Ved at se på respondenternes akademiske historik, operationaliseret som deres BAkarakter og deres oplevelser med opgavevejledning samt deres selvrapporterede tryghed ved at skulle skrive speciale, inddeler vi respondenterne i henholdsvis fagligt "sikre" og "usikre" specialeskrivere. Vi finder at de to grupper ligner hinanden, men også at fagligt usikre studerende i højere grad søger klarhed og struktur på processen, mens fagligt sikre studerende i højere grad søger fagligt modspil.

På baggrund af respondenternes svar anbefaler vi på linje med tidligere studier løbende dialogisk forventningsafstemning mellem vejleder og specialeskriver. En vigtig pointe er at forventninger og forforståelse er forskellige hos forskellige studerende; således rapporterer en overraskende stor andel af respondenterne at de har "særlige problemer" som kan komme i vejen for specialeprocessen. Det øger blot kravet om løbende forventningsafstemning.
\end{abstract}

\section{Indledning}

Højere uddannelse er en handelsvare og et mellemstatsligt konkurrenceparameter. Ifølge EU's officielle statistikbureau, Eurostat (2018), afsluttede ca. 4,7 millioner studerende en uddannelse fra en videregående uddannelsesinstitution i EU-området i 2016. De seneste årtier har set en voldsom stigning i antallet af færdiguddannede kandidater fra universiteter og dermed en voldsom stigning i antallet af specialer der skrives. Ifølge Danske Universiteter (2017: 16) var kandidatproduktionen fra danske universiteter i 2007 på i alt 12.807 og i 2017 på 24.467 (ovenikøbet med et lille fald fra 2016 til 2017). På trods af denne stigning bemærkes det at "[m]asters dissertations have attracted far less scholarly attention than Ph.D. theses despite their distinctive character and the worldwide proliferation of taught masters programmes" (Anderson, Day \& McLaughlin 2008: 33).

I den senere tid har vi i Danmark set indførelsen af den såkaldte fremdriftsreform som har betydet øgede krav til hurtig gennemførsel og som følgevirkninger en øget grad af "homogenisering" af specialeprocessen som skal afsluttes hurtigere og dermed bliver mere skemalagt. Det er samtidig sandsynligt at fremdriftsreform og andre tendenser i retning af at presse studerende hurtigere og billigere igennem universitetsuddannelser har medført et øget men-

${ }^{1}$ Kontakt: jthoegersen@hum.ku.dk 
talt pres på studerende. Det er i hvert fald hvad studenterrepræsentanter siger, og hvad foreløbige gennemførselsstatistikker viser (Universitetsavisen 2019).

Beslægtet med og som en konsekvens af varegørelsen og homogeniseringen af uddannelser beskriver Grant (2005) hvordan en såkaldt 'Techno-Scientific' og 'Neo-Liberal Commercial' diskurs om vejledning er ved at overtage traditionelle diskurser der fokuserede på enten "a supportive interpersonal relationship" (Grant 2005: 341), den såkaldte Psy-diskurs, eller på "intellectual sparring and confrontation" (ibid.), den såkaldte Trad-diskurs. Kendetegnende for Techno-diskursen er at den ser vejledning og specialeskrivning som "a predictable and orderly process of research skill training" (ibid.: 342), og at "[t]he malleable and obedient Techno-Student listens, tries and reports; the Techno-Supervisor observes, judges, instructs" (Ibid.: 343). Den Neo-Liberale Com-Student ser sig selv som "a consumer of services, and the Com-Supervisor as provider of those services" (ibid.). "Proper Supervision is the satisfactory exchange of services according to the terms of a consumer 'contract"' (ibid.). Vi kan her se hvordan relationen mellem specialeskriver og vejleder kan være kompleks og anledning til uklare forventninger, en pointe vi vender tilbage til nedenfor. Uklarheden og den usikkerhed den kan give anledning til, bliver naturligvis kun yderligere forstærket af det øgede mentale pres på studerende.

Da vejledning foregår bag lukkede døre, er det tilmed en praksis der kan være svær at undersøge. Vejledningens form er naturligvis underlagt en række bestemte, officielle krav fra universitetets side, men den formes tillige af vejleder og den vejledte. Forskellige vejledere har forskellige vejledningsmetoder, og forskellige studerende har forskellige forventninger, ønsker og behov (mere om dette nedenfor). Disse divergerende metoder, forventning, ønsker og behov fører til at man som deltager i vejledningssamtalen kan have svært ved at gennemskue eller forstå den andens kommunikative intentioner: "hvorfor spørger den studerende om det?", "hvorfor vil vejlederen have mig til det?", "er det virkelig det han/hun mener?". Med denne undersøgelse vil vi forsøge at afdække forventninger til specialevejledning og specialevejleder hos en årgang af specialeskrivere på et humanistisk universitetsinstitut. Formålet er at undersøge hvilke forventninger, erfaringer og ønsker de studerende går til vejledningen med, og vi vil samtidig illustrere hvorfor en italesat forventningsafstemning kan være hensigtsmæssig for et vellykket vejledningsforløb.

Som Wichmann-Hansen, Eika \& Mørcke (2007: 11) skriver, er "vejledning [...] på mange måder en overset undervisningsform på universitetet, selvom den enkelte universitetslærer ser vejledning som en central metode til at fremme studerendes læring og faglige udvikling". Specialet ses (i hvert fald på "de bløde fag") som kronen på værket og endemålet for mange års studieliv. Det er uddannelsens svendestykke og kan næsten betragtes som en overgangsrite (Van Gennep 1909) der markerer den studerendes optagelse i det faglige fælleskab og et identitetsskifte fra "elev" til "faglig ekspert". Måske på grund af den store betydning der lægges på specialet, er specialet og arbejdet med specialet også omgærdet med næsten mytologisk respekt og ærefrygt. Næsten alle studerende har hørt og fortalt skrækhistorier om specialeprocesser der løb af sporet og førte til "specialesump", ensomhed, stress, depressioner osv., og tilsvarende om de sagnomspundne specialeprocesser der forløb gnidningsfrit, med overskud og afsluttet i god tid. Det er oplagt at studerende der står foran specialeskrivningen, har komplicerede forståelser, følelser og forventning til det livsprojekt de skal give sig i kast med; og tilsvarende at de kigger indad og spørger sig selv hvem de selv er, og hvordan de vil håndtere de forventede udfordringer: "er jeg sådan en som bliver deprimeret?", "vil jeg 
kunne danse gennem specialet som NN gjorde?", "er jeg god nok, og gør jeg det godt nok?" med andre ord.

Det er lige så oplagt at specialeskrivere in spe har komplicerede forventninger til den vejleder der fungerer som den institutionelle guide gennem specialeskrivningsprocessen. Hvor specialeskrivning for specialeskriveren er en ny og uklar fremtid man kun kan gøre sig tanker om, er specialeskrivning for vejlederen en kendt fortidserfaring som hun eller han har oplevet både gennem sin egen specialeskrivning (og ph.d.-skrivning) og på andenhånd som vejleder for andre. Samtidig er vejleder også faglig bedømmer og gate keeper. På det konkrete institut vi undersøger, er vejlederen helt officielt bedømmer på specialet, men også mere uformelt er (og opfattes) vejleder (som) en figur der vurderer og bedømmer specialeskriverens faglighed, vaner, arbejdsindsats osv. Mainhard et al. (2009: 360) beskriver dette som at "a certain tension might exist between the supportive helping role of the supervisor and the requirements of the role to warrant dissertation quality". De låner begreber fra Murphy et al. (2009) og taler om denne dobbeltrolle som 'assessor' og 'guide'. Endelig har vejleder også funktion af kritiker af specialeskriverens tekst og ideer. Den studerende kan forvente at alle udsagn vil blive analyseret og udfordret, og en tredje rolle kan altså beskrives som 'kritikeren'. Vejlederens og specialeskriveren har altså et komplekst forhold til hinanden hvor vejlederen både er guide, hjælper og samvittighed, anklager, forsvarer og dommer.

For at samarbejdet mellem specialeskriver og specialevejleder kan fungere, er det nødvendigt at de to parter kender hinandens mål, interesser og forventninger. Wichman-Hansen \& Jensen (2013) foreslår at parterne diskuterer hinandens forventninger med udgangspunkt i et "forventningsskema" (ibid.: 335). Et sådant skema og den forventningsafsøgning som det giver anledning til, giver parterne mulighed for at vide hvor hinanden kommer fra, så at sige og at forhandle sig frem til et fælles (ofte mangesidet) mål - fx "et godt speciale", "en høj karakter", "faglig udvikling", "personlig udvikling" osv.

For at få et bedre indblik i specialevejledningsprocessen har vi iværksat et projekt der undersøger specialevejledning dels gennem optagelser af vejledningssamtaler, dels gennem interviews med specialeskrivere og -vejledere og dels gennem spørgeskemaer sendt til nystartede specialeskrivere. Det er det sidste vi afrapporterer her - altså en spørgeskemaundersøgelse med nystartede specialestuderende om deres forventninger til specialeskrivningsprocessen samt deres forventninger og ønsker til vejlederen og vejledningen. Fordelen ved spørgeskemaet som supplement til de øvrige datatyper er dels at det tillader at undersøge en større og mere repræsentativ gruppe end observationer og kvalitative interview, dels at den anonyme, upersonlige henvendelse som studerende er vant til bl.a. fra evalueringsskemaer, giver mulighed for andre typer af svar end de mere involverede, kontekstuelt afhængige, intersubjektivt forhandlede svar som et kvalitativt interview giver anledning til (se fx Kvale \& Brinkmann 2015).

\section{Tidligere undersøgelser af forventninger og baggrund for succesfulde vejledningsforløb}

Wichmann-Hansen, Eika \& Mørcke (2007) præsenterer et metastudie af tidligere danske og internationale studier af akademisk vejledning, og den hovedkonklusion de uddrager af de behandlede studier, er at "en vellykket vejledningsproces først og fremmest afhænger af en god relation mellem den studerende og vejlederen", og at "studerende først og fremmest lagde vægt på at vejlederen var tilgængelig for vejledning (både fysisk og mentalt), og at vejlederen læste deres tekstoplæg grundigt og gav konstruktiv feedback herpå. Kun sekundært 
lagde studerende vægt på, at vejlederne havde faglig indsigt i forskningsfeltet" (ibid.: 14). Når studerende kritiserer den vejledning de modtager, drejer det sig om "mangel på - eller direkte fravær af - vejlederens tid, følelsesmæssige støtte og interesse" (ibid.), mens vejlederens faglige ekspertviden altså er sekundær. Opfattelsen af at specialeskriver-vejleder-forholdet skal beskrives i forhold til (mindst) to dimensioner, går igen i mange beskrivelser. Som De Kleijn et al. (2012: 926) siger i en gennemgang af tidligere studier: "the relationship can be described by means of two dimensions, which are given various names: intimacy and direction [...], supporting and structuring [...], cold - warm and structure - free [...], professional role - personal self and dependence - independence [...] affiliation and power [...], and proximity and influence". De Kleijn et al. bruger selv begreberne 'affiliation' og 'control', mens Greenbank \& Penketh (2009: 468) taler om "the [...] perceived need to scaffold and support dissertation students, whilst at the same time facilitating and encouraging independent thinking".

Den vægtning af "personlig relation" over "faglighed" som betones af Wichmann-Hansen, Eika \& Mørcke, går igen i valget af vejleder ( $\mathrm{d}$ det omfang den studerende har ret til og mulighed for selv at vælge sin vejleder): I universiteternes regler og i vejledernes fællesskab fokuseres der på at vejlederen udpeges primært på baggrund af faglige kvaliteter; men når studerende begrunder deres valg af vejleder, fokuserer de oftere på interpersonelle kvaliteter (Wichmann-Hansen, Eika \& Mørcke 2007: 15; se også Andersen \& Jensen 2007). De Kleijn et al. (2012) viser en klar lineær sammenhæng mellem specialeskriverens oplevelse af 'affiliation' til vejlederen og både tilfredshed og (i mindre grad) specialekarakter. Relationen mellem oplevet 'control' og henholdsvis tilfredshed og karakter er mere kompleks. For karakter er sammenhængen U-formet sådan at elever der oplevede høj eller lav grad af 'control' fra deres vejledere, klarede sig bedre end dem der oplevede middelhøj grad af 'control'. For tilfredshed er sammenhængen omvendt U-formet sådan at dem der oplevede høj eller lav grad af 'control', var mindre tilfredse med deres vejledning end dem der oplevede middel-'control' (Ibid. 934ff.). Eller som Demb \& Funk (1999: 23) beskriver det: "students wanted faculty to offer a complex and balanced blend of guidance and autonomy. Too much of either created problems".

Dette skel mellem hvad studerende finder vigtigt, den personlige relation til vejlederen, og hvad institutionen finder vigtigt, vejlederens faglighed, kan ses som et eksempel på forskellige for-forståelser eller forskellige forventninger til vejledning og til relationen mellem vejleder og studerende. Flere af de studier som Wichmann-Hansen, Eika \& Mørcke (2007) gennemgår, peger på sådanne problemer med "ulige og uafklarede forventninger parterne [vejleder og studerende] imellem" (ibid.). Fx fandt Jensen (1992) at studerende søger tryghed og en grad af blåstempling fra deres vejleder, mens vejlederen i højere grad fokuserer på de faglige diskussioner. Med en simplificering kan man sige at den studerende i vejlederen søger en autoritetsfigur som kan legitimere den studerendes arbejde. Eller sagt på en anden måde: I en verden af uklare kvalitetskriterier ønsker den studerende et fast holdepunkt som kan garantere at den studerendes kvalitetsniveau er velkalibreret. Som Anderson et al. (2008: 43f.) beskriver det: Specialeskrivere "expected that supervisors would use their expert knowledge to assist them to meet the demands of a new task and to satisfy appropriate academic standards".

Denne navigation imellem forskellige roller er ofte diskuteret i litteraturen og ikke mindst $\mathrm{i}$ "håndbogslitteraturen" for vejledere (fx Rienecker, Harboe \& Jørgensen 2005; Tofteskov 1996; se også Andersen \& Jensen 2007; Handal \& Lauvås 1997, 1998). 
Et potentielt mismatch af ønsker og forventninger især i forbindelse med oppositionen mellem vejlederens "personlige kvaliteter" over for "faglige kvaliteter" er et vigtigt element i denne undersøgelse. På den ene side ønsker vi at dykke ned i studerendes forventninger til deres egen og vejleders roller og studerendes forventninger til relationen med deres vejleder; på den anden side ønsker vi at udforske to udfordringer af det ellers meget klare billede som tidligere studier har tegnet af specialeskriveres prioriteter. For det første forventer vi at de ændringer i (universitets)pædagogik som vi har været vidne til i Skandinavien over de seneste årtier, fx manifesteret som fremdriftsreformen som vi nævnte ovenfor, kan have sat sig spor sådan at studerende i dagens Danmark prioriterer anderledes end deres forældres generationer. Fokus i nyere tids pædagogik har i høj grad været studenterautonomi. Siden folkeskolen har vore dages studerende lært at de skal tage ansvar for egen læring og at se underviseren som en sparringspartner mere end som en kilde til autoritative svar. Man kunne forestille sig at det har sat sig spor sådan at studerendes prioriteter har ændret sig og måske i højere grad ligner institutionens. Hvis studerende har internaliseret institutionernes pædagogiske idealer, kunne man forestille sig at se en ændring. Omvendt kan man også med Grants (2005) ord nævnt ovenfor forvente at studerende i højere grad ser sig selv som 'Technostuderende' med en klar og veldefineret opgave at løse - som defineres af vejleder som en del af deres 'consumer contract'.

En anden indvending drejer sig om de studerende selv. De fleste af de ovennævnte studier angriber specialeskrivere som en relativt homogen gruppe med ens ønsker, forventninger og reaktioner. Det stemmer dårligt overens med vores opfattelse af en meget divers - og meget individualiseret - studenterpopulation. Der var måske engang hvor universitetsstuderende udgjorde en homogen gruppe med stort set identisk social baggrund og stort set identiske ønsker for deres fremtidige liv. Hvis der var, er den tid i hvert fald overstået med vore dages masseuniversitet. Vores studerende kommer fra meget forskellige sociale vilkår og fra mange forskellige kulturer, de har meget forskellige forudsætninger for at gennemføre deres studier, og de har meget forskellige ambitioner med deres studier. At angribe dem som én homogen gruppe med ens ønsker kan udradere mange vigtige forskelle og give et fortegnet billede. Forskere som fx Demb \& Funk (1999) har været fokuseret på de komplekse og ofte modstridende ønsker som studerende har til deres undervisere og vejledere. Men vi er ikke stødt på studier som forsøger at analysere om der er faktorer ved en specialestuderende der kan forudsige dennes ønsker og behov.

Rienecker, Harboe \& Jørgensen (2005: 269ff.) åbner for diskussionen om forskellige typer af studerende i et kapitel om "problemstuderende". Disse studerende kategoriseres i forskellige "forsinkertyper": "perfektionisten, teoretikeren, praktikeren, udsætteren, døgnbrænderen, den deprimerede" (ibid.: 269). Diskussionen viser en opmærksomhed om at forskellige studerende kan have forskellige udfordringer og forskellige typer af uhensigtsmæssige arbejdsformer som vejlederen må forholde sig til. Man kunne også forvente at disse forskellige studentertyper ville udtrykke forskellige behov og ønsker til deres vejleder og måske endda opfatte vejlederens formål og roller (som beskrevet ovenfor) vidt forskelligt.

Andre studier (Jensen \& Christensen 2012: 9ff.) har betonet hvordan studerende har forskellige vejledningsbehov: faglig vejledning, metodevejledning, procesvejledning, samt behov for at inddrage personlige elementer og få social kontakt. Tilsvarende, som nævnt ovenfor, har fx Handal \& Lauvås (2007) og Anderson et al. (2008) betonet hvordan behovene ændrer sig i løbet af projektet: Det er andre ting man har brug for hjælp til, og andre vejlederroller man som specialeskriver har brug for efterhånden som projektet (og man selv og den interperso- 
nelle relation) udvikler sig. Ingen af de to går dog så vidt vi kan se, ind i at diskutere forskelle på studerende, og hvordan tidligere erfaringer kan spille ind på konkrete behov.

Vi mener at det er overordentligt relevant at se på forskelle i gruppen af specialeskrivere og undersøge om vi kan finde sådanne mønstre i behov og opfattelser korreleret med "typer af studerende". Som et meget simpelt eksempel på forskelle mellem studerende kan man, som vi vil gøre nedenfor, se på forskelle mellem fagligt "sikre" og "usikre" studerende. Vi indrømmer at skellet er simplistisk, men ingen vil vel benægte at nogle studerende har vanskelligere ved det akademiske indhold og den akademiske form end andre, og at denne forskel kan føre til forskellige arbejdsformer og forskellige vejledningsønsker?

Undersøgelsen her er i høj grad inspireret af Harboe \& von Müllens (2006) undersøgelse af "De studerendes forventninger til specialevejledning". Harboe \& von Müllen undersøgte forventninger til specialevejledning hos godt 250 studerende på Københavns Universitets samfundsvidenskabelige og juridiske fakultet. Deres interesse er især mødet mellem de studerendes forventninger og de institutionelle rammer og muligheder som kan komme på tværs af disse forventninger, og dermed, kan man sige, er deres perspektiv faktisk mere på institutionens interesser end på de studerendes. De studerendes forventninger bliver beskrevet som potentielt problematiske og afdækningen af forventninger dermed som en undersøgelse af potentielle kilder til konflikt. Fx fremhæver Harboe i et interview (Lauridsen 2006) at det i høj grad er urealistisk når et flertal af de studerende forventer at vejleder gennemlæser og godkender det endelige speciale, og at de studerende har urealistiske forventninger til vejledningsmødernes antal og længde. De studerende forventer en grad af service som universitetet ikke kan (eller vil) levere. Harboe \& von Müllens primære konklusion er derfor at der skal etableres en højere grad af forventningsafstemning tidligt i vejledningsforløbet så studerende ikke bliver skuffet på grund af urealistiske forventninger som ikke bliver indfriet. Vi er $\mathrm{i}$ udgangspunktet helt enige i Harboe \& von Müllens konklusion - forventningsafstemning er godt og nødvendigt for en vellykket vejledningsproces. Men i modsætning til Harboe \& von Müllers fokus på de institutionelle rammer er vores fokus i højere grad på de studerendes mentale forberedelse og tanker om specialet og dermed de forforståelser om specialeskrivningen som danner grundlag for vejledningsmødet mellem studerende og vejleder.

\section{Metode}

Et spørgeskema blev udformet i Google Analyse (https://www.google.com/forms/about/, se appendiks). Spørgeskemaets målgruppe var alle studerende på dansksprogede uddannelser ved Institut for Nordiske Studier og Sprogvidenskab ved Københavns Universitet som startede deres specialeskrivning i 20182. Spørgeskemaet blev udsendt i to omgange: Til dem der startede i foråret, blev det udsendt i februar og marts, og til dem der startede i efteråret, $\mathrm{i}$ august. Da vi havde etiske bekymringer om hvorvidt spørgeskemaet kunne påvirke forholdet mellem vejleder og studerende (ved $\mathrm{fx}$ at stille studerende forventninger $\mathrm{i}$ udsigt som vejleder ikke havde til hensigt at indfri), bad vi først om vejlederes tilsagn før vi sendte spørgeskemaet til deres studerende. Vi er opmærksomme på at dette fører til en potentiel skævhed i stikprøven - en skævhed som yderligere forstærkes af at specialeskriverne frivilligt kan væl-

\footnotetext{
${ }^{2}$ Instituttet har en enkelt engelsksproget uddannelse som blev udeladt af undersøgelsen fordi de studerende på den for en stor dels vedkommende er udenlandske. De blev frasorteret dels for at vi ikke skulle oversætte spørgeskemaet (med konsekvenser for sammenligneligheden), og dels for at vi ikke skulle forholde os til respondenter som har deres erfaringer fra en anden undervisningskultur og dermed potentielt helt andre livsverdenserfaringer.
} 
ge at undlade at svare på spørgeskemaet. Respondenterne blev ikke direkte gjort opmærksomme på at deres vejleder havde givet tilsagn, men kun specialeskrivere hvis vejleder havde givet tilsagn, fik tilsendt opfordring til at besvare spørgeskemaet. Af i alt ca. 200 specialeskrivere der startede deres speciale i 2018, blev spørgeskemaet sendt ud til 131, og 79 af disse svarede på spørgeskemaet. Det svarer til en besvarelsesprocent på 60, og at vi har indhentet svar fra ca. $40 \%$ af den samlede population af specialeskrivere. Det siger sig selv at alle kvantitative undersøgelser med så relativt få respondenter (79) og så relativt lille svarprocent (40) skal tages med behørigt forbehold. Desuden må man have i tankerne at der her kun undersøges ét institut på ét universitet. Resultaterne kan højst ses som indikative for større strømninger og indlæg i en diskussion; man må være meget forsigtig med at generalisere til alle danske specialeskrivere.

\section{Datamateriale}

Af disse er 64 kvinder, 14 er mænd, og én identificerer sig som "kamphelikopter" (eller benyttede måske den åbne kategori til lidt polemik). Gennemsnitsalderen er 27 år med en standardafvigelse på 3,2 år. Den yngste er 23, den ældste 41. Fordelingen på baggrundsvariabler giver dårligt mulighed for sammenligning af køn eller aldersgrupper. Der er for få mænd til at kønssammenligningen rigtig giver mening, og aldersmæssigt er respondenterne så homogene at der heller ikke her er basis for en sammenligning. Tre fjerdedele af respondenterne opgiver at de har arbejde ved siden af studierne, mellem 5 og 30 timer om ugen.

Tabel 1. Baggrundsvariabler blandt respondenterne

\begin{tabular}{|c|c|c|c|c|c|c|c|c|}
\hline \multicolumn{2}{|l|}{ Køn } & \multicolumn{2}{|c|}{ Alder } & \multirow{2}{*}{$\begin{array}{l}\begin{array}{l}\text { Arbejde ved } \\
\text { siden af stu- } \\
\text { dierne }\end{array} \\
\text { Har arbejde }\end{array}$} & \multicolumn{4}{|c|}{ Uddannelse } \\
\hline Kvinde & Mand & $\begin{array}{l}\text { Mid- } \\
\text { del }\end{array}$ & $\begin{array}{l}\text { Std. } \\
\text { afv. }\end{array}$ & & $\begin{array}{l}\text { Audio- } \\
\text { logo- } \\
\text { pædi }\end{array}$ & Dansk & $\begin{array}{l}\text { Lingvi- } \\
\text { stik }\end{array}$ & $\begin{array}{l}\text { Sprog- } \\
\text { psykologi }\end{array}$ \\
\hline $81 \%$ & $18 \%$ & 27,3 & 3,2 & $75 \%$ & $10 \%$ & $54 \%$ & $1 \%$ & $33 \%$ \\
\hline
\end{tabular}

Godt halvdelen af respondenterne læser Dansk, en tredjedel læser Sprogpsykologi og 10 \% læser Audiologopædi. Det svarer nogenlunde til sammensætningen i hele populationen af specialeskrivere, dog med en lille overvægt at Sprogpsykologi-studerende og en lille underrepræsentation af Lingvistik-studerende. Vi har ingen særlige hypoteser om forskelle mellem uddannelserne eller for den sags skyld at en sammenligning af de relativt ens uddannelser skulle vise noget interessant. Det er langt mere interessant hvis der bliver mulighed for at sammenligne fx humaniorastuderende med samfunds- eller naturfaglige studerende.

Statistisk analyse

Analysen er grundlæggende komparativ på flere forskellige måder. I stedet for at opgive hvor stor en andel af respondenterne der erklærer sig enige eller uenige i de forskellige spørgsmål, sammenligner vi enten svarenes relative "popularitet" eller forskellige grupper af studerendes svar på samme spørgsmål - dvs. variansanalyser af sammenhængen mellem grupper og responser. I stedet for $\mathrm{fx}$ at konkludere at $30 \%$ af de studerende har svaret at de ønsker en vejleder som er "åben for deres ideer", vil vi hellere fokusere på om dette kendetegn vur- 
deres højere end fx en "opmuntrende" eller en "erfaren" vejleder. Tilsvarende vil vi ofte fokusere på om der er forskelle på hvad man med forbehold kan kalde fagligt "sikre" og "usikre" studerende, og om der således er systematisk forskellige forventninger blandt forskellige typer af studerende. Rationalet er at "absolutte" frekvenser (som fx "30 \% af de studerende synes...") er meget følsomme for spørgsmålsformuleringernes ordlyd: "jeg synes det er vigtigt", "jeg synes det er meget vigtigt" og "jeg synes at det er essentielt" vil således kunne give forskellige grader af tilslutning og dermed vidt forskellige fortolkninger af resultatet. Når man ser på forskelle mellem ensformulerede spørgsmål eller mellem respondenter som har svaret på samme spørgsmål, er man mindre følsom for den konkrete formulering. I enkelte tilfælde er det muligt at lave korrelationsanalyser som sammenligner respondenters svar på forskellige spørgsmål.

Svarene blev renset og behandlet i SPSS (version 23). Statistisk signifikans er testet med ikkeparametriske tests da svarkategorierne i de fleste tilfælde er på ordinal- eller nominalskalaniveau. Vi benytter $\mathrm{chi}^{2}$ ved test af nominale variabler, Mann-Whitney $U$ ved test af to gruppers svar på ordinalskalaniveau og Kruskal-Wallis $\mathrm{H}$ ved test af flere end to grupper på ordinalskalaniveau og Pearson correlationcoefficient ved test af korrelationer. Den konkrete test og pværdi opgives i hvert tilfælde.

\section{Analyse og resultater}

Udover den heuristiske udforskning af de specialestuderendes forventninger, undersøger analysen nogle underliggende hypoteser om at forskellige typer af studerende har forskellige forventninger og forskellige behov. Udover køn og alder, som vi altså dårligt kan undersøge i dette udvalg, opererer vi med en meget grov opdeling i "fagligt sikre" over for "fagligt usikre" studerende. Beskrivelserne skal tages med et behørigt gran salt. Når vi taler om "fagligt usikre", er det en relativ størrelse som vi bruger i en grov analytisk inddeling. Mere rammende udtryk ville måske være "den fagligt meget sikre" over for "den jævnt sikre" studerende eller tilsvarende, men vi vælger de kortere beskrivelser af pladshensyn. Det turde være klart at vi ikke mener at kategorierne fagligt "sikre" og "usikre" på nogen måde er udtømmende. Det er naturligvis ikke sådan at alle "sikre" henholdsvis "usikre" er ens på alle punkter. Opdelingen i fagligt sikre og usikre er som sagt en analytisk - og relativt artificiel - operationalisering af forskellige historikker, erfaringer og følelser. På trods af disse forbehold håber vi at de giver os et indblik i sammenhænge mellem tidligere studiemæssige erfaringer og forventninger som kan være produktive i vejledningsprocessen.

Man kan kritisk overveje om "sikkerhed" er et endimensionelt fænomen eller om det består af to uafhængige dimensioner som man kunne kalde "faglighed" og "tryghed": Den fagligt stærke studerende er jo ikke nødvendigvis tryg ved sin egen faglighed. Vi kan pege på (pressens yndlings-stereotype studerende) "12-tals-pigen" som eksempel på en fagligt stærk, men også utryg studerende. Omvendt kunne man forestille sig studerende der ved at de er fagligt jævne, men hviler trygt i det og er tilfredse med de resultater de får ud af deres indsats.

For at operationalisere kategorien "sikkerhed" stillede vi en række spørgsmål som på forskellig måde afsøger studerendes faglighed og tryghed ved specialeskrivningen: Det faglige niveau undersøgte vi ved at spørge om karakteren for BA-opgaven da det som regel er den sidste større opgave studerende har skrevet. Tryghed undersøgte vi dels ved at spørge direkte "hvordan har du det med at skulle skrive speciale", dels ved at spørge til tidligere erfaringer 
med vejledning - under antagelsen at tidligere negative erfaringer fører til øget utryghed omkring specialeprocessen og den kommende vejledning (se tabel 2-4).

Tabel 2. Svar på spørgsmålet: "Hvilken karakter fik du for dit BA-projekt?"

\begin{tabular}{lll}
\hline \hline BA-karakter & Frekvens & Procent \\
\hline 2 & 1 & 1,3 \\
4 & 9 & 11,4 \\
7 & 19 & 24,1 \\
10 & 26 & 32,9 \\
12 & 24 & 30,4 \\
\hline Total & 79 & 100,0 \\
\hline \hline
\end{tabular}

Tabel 3. Svar på spørgsmålet: "Hvordan har du det med at skrive speciale?"

\begin{tabular}{lcc}
\hline \hline Følelser for at skrive speciale? & \multicolumn{2}{l}{ Frekvens Procent } \\
\hline 1 (Jeg frygter det) & 1 & 1,3 \\
2 & 3 & 3,8 \\
3 & 11 & 13,9 \\
4 & 15 & 19,0 \\
5 & 24 & 30,4 \\
6 & 18 & 22,8 \\
7 (Jeg er helt tryg ved det) & 7 & 8,9 \\
\hline Total & 79 & 100,0 \\
\hline \hline
\end{tabular}


Tabel 4. Svar på spørgsmålet: "Hvad er din tidligere erfaring med vejledning?"

\begin{tabular}{lll}
\hline \hline Vejledningserfaringer & Frekvens & Procent \\
\hline 1 (Meget positiv) & 22 & 27,8 \\
2 & 27 & 34,2 \\
3 & 21 & 26,6 \\
4 & 4 & 5,1 \\
5 (Meget negativ) & 5 & 6,3 \\
\hline Total & 79 & 100,0 \\
\hline \hline
\end{tabular}

Man kan med rimelighed indvende at BA-karakter er et upræcist mål for fagligt niveau, og at "tidligere erfaringer med vejledning" er for diffust til at give brugbare svar. Som man kan se i tabel 5, korrelerer svarene på de tre spørgsmål dog med hinanden: Dem der fik de højeste BA-karakterer, har de mest positive erfaringer med vejledning; og dem der har de mest positive erfaringer, er mest trygge ved at skulle skrive speciale. Følger man Cohens (1988) fortolkning, kan korrelationen på 0,36 fortolkes som "moderat" og klart statistisk signifikant. Der er også en ("svag" og ikke statistisk signifikant) sammenhæng mellem BA-karakter og tryghed ved at skulle skrive speciale.

Tabel 5. Korrelation mellem BA-karakter, tidligere vejledningserfaringer og følelser for $\mathrm{i}$ forbindelse med at skulle skrive speciale

\begin{tabular}{|c|c|c|c|}
\hline & & $\begin{array}{l}\text { Hvad er din } \\
\text { tidligere erfa- } \\
\text { ring med vej- } \\
\text { ledning? }\end{array}$ & $\begin{array}{l}\text { Hvilken karak- } \\
\text { ter fik du for } \\
\text { dit BA-projekt? }\end{array}$ \\
\hline $\begin{array}{l}\text { Hvordan har du det med at skul- } \\
\text { le skrive speciale? }\end{array}$ & $\begin{array}{l}\text { Pearson Korrelation } \\
\text { Sig. (1-halet) } \\
\text { N }\end{array}$ & $\begin{array}{l}-, 362^{* *} \\
, 001 \\
79\end{array}$ & $\begin{array}{l}202 \\
075 \\
79\end{array}$ \\
\hline $\begin{array}{l}\text { Hvad er din tidligere erfaring } \\
\text { med vejledning? }\end{array}$ & $\begin{array}{l}\text { Pearson Korrelation } \\
\text { Sig. (1-halet) } \\
\text { N }\end{array}$ & & $\begin{array}{l}-, 392^{* *} \\
<, 001 \\
79\end{array}$ \\
\hline
\end{tabular}


Fordi de tre mål for sikkerhed korrelerer i høj grad (og for at gøre analysen mere overskuelig), slår vi de tre mål sammen i én "sikkerhedsscore"3 og deler populationen i to, "de fagligt sikre" vs. "de fagligt usikre".

Der er ingen sammenhæng mellem denne "sikkerhedsscore" og alder eller mængden af arbejde uden for studierne. Og der er heller ingen forskel imellem de to køn. Der er imidlertid en signifikant sammenhæng mellem studieretning og sikkerhedsscore, studerende på Sprogpsykologi og især på Dansk er mindre sikre end audiologopædi-studerende.

"Faglig sikkerhed" operationaliseres som sagt ud fra de tre spørgsmål i tabel 5, og vi deler simpelthen respondenterne i de $50 \%$ mest "sikre" over for de $50 \%$ mindst "sikre". Der er (naturligvis) klare forskelle på de to grupper med hensyn til de tre nævnte variabler - grupperingen er jo netop baseret på de tre variable.

Tabel 6. Sammenligning af " fagligt sikre" og " fagligt usikre" studerendes BA-karakter, tidligere vejledningserfaringer og følelser for i forbindelse med at skulle skrive speciale

\begin{tabular}{|c|c|c|c|c|}
\hline & $\begin{array}{l}\text { Hvilken karakter } \\
\text { fik du for dit BA- } \\
\text { projekt? }\end{array}$ & $\begin{array}{l}\text { Hvordan har } \\
\text { du det med at } \\
\text { skrive } \\
\text { speciale? }\end{array}$ & $\begin{array}{l}\text { Hvad er din } \\
\text { tidligere erfa- } \\
\text { ring med } \\
\text { vejledning? }\end{array}$ & Total \\
\hline Fagligt usikre & 7,54 & 3,95 & 2,97 & 39 \\
\hline Fagligt sikre & 10,63 & 5,58 & 1,60 & 40 \\
\hline
\end{tabular}

I de følgende analyser undersøger vi som sagt den relative frekvens af forskellige svar på centrale spørgsmål i undersøgelsen. Derudover sammenholder vi svar med " fagligt sikre" vs. " fagligt usikre" studerende. Gennemgangen er delt i fire dele: Første del handler om forventninger til specialearbejdet, dels til arbejdsprocessen og dels til resultatet; anden del behandler de studerendes arbejdsform, deres indsigt i sig selv som specialeskrivere kan man sige; tredje del behandler valget af vejleder og de overvejelser der går ind i det; og endelig behandler fjerde og sidste del forventninger og ønsker til vejleder, både i form af den mere formelle udfyldelse af vejlederrollen og i form af mere personlige sider af forholdet; det er altså her vi vender tilbage til vejledningens roller som diskuteret ovenfor.

\section{Forventninger til specialearbejdet}

Første afsnit af analysen handler om (forskellige grupper af specialeskriveres forskellige) forventninger til specialets resultat og specialearbejdet og til hvad de forventer af sig selv i forbindelse med specialeskrivningen

\footnotetext{
${ }^{3}$ Rent praktisk gjorde vi det ved at lave en faktoranalyse på de tre spørgsmål og begrænse modellen til én faktor. Hver respondents score på denne faktor blev derefter tilskrevet respondenten som en ny variabel. Man kan sammenligne det med et vægtet gennemsnit af den enkeltes svar på de tre spørgsmål hvor man tager højde for at et af spørgsmålene muligvis er mere centralt for den underliggende dimension end andre spørgsmål er (se Field 2014 for en beskrivelse af faktoranalyse).
} 


\section{Forventninger til karakter}

Første spørgsmål forsøger at afdække forventninger til specialets resultat, konkret operationaliseret som den forventede karakter, se tabel 7. Det er sandsynligt at der er en vis overrapportering (at man opgiver hvad man håber, lige så meget som hvad man realistisk forventer), men det er stadig relevant at se hvor høje forventningerne til specialekarakter er, og i hvilket omfang de korrelerer med "sikkerhed".

Tabel 7. Forventet specialekarakter sammenholdt med sikkerhedsscore

\begin{tabular}{lcccccc}
\hline \hline \multicolumn{7}{c}{ Hvilken karakter forventer du at få for dit } \\
speciale? & & & & & \\
Sikkerhedsscore & 2 & 4 & 7 & 10 & 12 & Total \\
\hline Fagligt usikker & 1 & 1 & 13 & 16 & 8 & 39 \\
Fagligt sikker & 0 & 0 & 4 & 19 & 17 & 40 \\
\hline Total & 1 & 1 & 17 & 35 & 25 & 79 \\
\hline \hline
\end{tabular}

Gennemsnit for alle respondenterne er 9,8, og der er marginalt højere forventninger blandt de fagligt sikre specialeskrivere $(10,55$ vs. 9,05$)$. Forskellen er statistisk signifikant (MannWhitney $U, p=0,003$ ).

\section{Personlige forhold der kan påvirke arbejdet}

Vi spurgte til om der var personlige forhold der kunne indvirke på arbejdsevnen (og potentielt forsinke projektet). Som eksempler gav vi "psykiske udfordringer, privatliv eller fysisk funktionsnedsættelse" (se spørgeskemaet i sin fulde ordlyd i appendiks). Knap halvdelen af respondenterne svarer ja til dette spørgsmål (se tabel 8). Som man kan se, er andelen så godt som ens for de fagligt sikre og usikre studerende.

Tabel 8. Svar på spørgsmålet "er der personlige forhold, der kan indvirke på din arbejdsevne (såsom psykiske udfordringer, privatliv eller fysisk funktionsnedsættelse)?"

Er der personlige forhold, der kan indvirke på din arbejdsevne?

\begin{tabular}{lcc} 
Sikkerhedsscore & Ja & Total \\
\hline Fagligt usikker & $46 \%$ & 39 \\
Fagligt sikker & $45 \%$ & 40 \\
\hline Total & 36 & 79 \\
\hline \hline
\end{tabular}


Studerende der rapporterer om "særlige forhold der kan påvirke arbejdet" forventer i gennemsnit at få lidt højere karakter for specialet $(10,2$ mod 9,5), men forskellen er ikke signifikant $\left(\mathrm{chi}^{2}, \mathrm{p}=0,11\right)$.

Deltagerne er også blevet bedt om at beskrive karakteren af de "personlige forhold". 30 eller knap halvdelen af alle respondenter har besvaret spørgsmålet og beskriver forhold som stress, depression, graviditet og små børn, kronisk sygdom samt alvorlig sygdom og dødsfald i familien.

\section{Forventninger til arbejdspres}

Med dette spørgsmål undersøger vi hvilken arbejdsbelastning specialeskriverne regner med at specialearbejdet kommer til at udgøre. Spørgsmålet er stillet åbent for at undgå at svarkategorier kunne give respondenterne en antydning af hvad ønskværdige svar kunne være. Mange har (naturligt nok) svaret med en omtrentlig angivelse a la "12-15 timer" eller "ca. 20 timer". Svarene er grupperet sådan at de bedst muligt svarer til kategorierne i tabel 9. Det giver derfor ikke mening at operere med gennemsnit, men man kan konkludere at typetallet ligger på kategorien 20-24 timer, mens medianen ligger i kategorien 25-29 timer, eller mellem $1 / 2$ og $3 / 4$ tid af en arbejdsuge.

Tabel 9. Forventet arbejdstid på specialet per uge sammenholdt med sikkerhedsscore

Arbejdstid

Sikkerhedsscore $<15$ timer 15-19 timer 20-24 timer 25-29 timer 30-34 timer $>=35$ Total

\begin{tabular}{lccccccc}
\hline Fagligt usikker & 3 & 2 & 13 & 12 & 4 & 5 & 39 \\
Fagligt sikker & 0 & 2 & 14 & 8 & 10 & 6 & 40 \\
\hline Total & 3 & 4 & 27 & 20 & 14 & 11 & 79 \\
\hline
\end{tabular}

Det virker rimeligt at tro at der bliver overrapporteret en del, altså at man i hvert fald ikke opgiver færre timer end man regner med at komme til at bruge - uden at det nødvendigvis er en særlig god indikation af hvor meget tid man faktisk kommer til at bruge. Der er lidt højere forventninger til arbejdsbyrde blandt de fagligt sikre specialeskrivere, men igen er forskellen ikke signifikant (Mann-Whitney $U, p=0,224$ ).

\section{Arbejdsformer}

I spørgsmål 7 blev deltagerne bedt om at karakterisere deres egen arbejdsform. Vi var interesseret $\mathrm{i}$ at vide mere om specialestuderendes selvopfattede arbejdsform og -disciplin end der oplyses med et simpelt timetal. Vi var desuden interesseret i om der kan spores forskellige tendenser imellem fagligt "sikre" og "usikre" studerende. Man kunne forestille sig at fagligt sikre studerende havde udviklet mere stabile arbejdsformer - måske endda at deres øgede sikkerhed er en konsekvens af deres arbejdsformer.

Deltagerne blev præsenteret for seks svarmuligheder og havde mulighed for at afkrydse en eller to. Søjlernes højde i figur 1 opgiver procentandelen af deltagere som har afkrydset hver 
af kategorierne, rangeret efter stigende enighed. Tallene over hver søjle angiver antallet af respondenter der har erklæret sig enige i udsagnet.

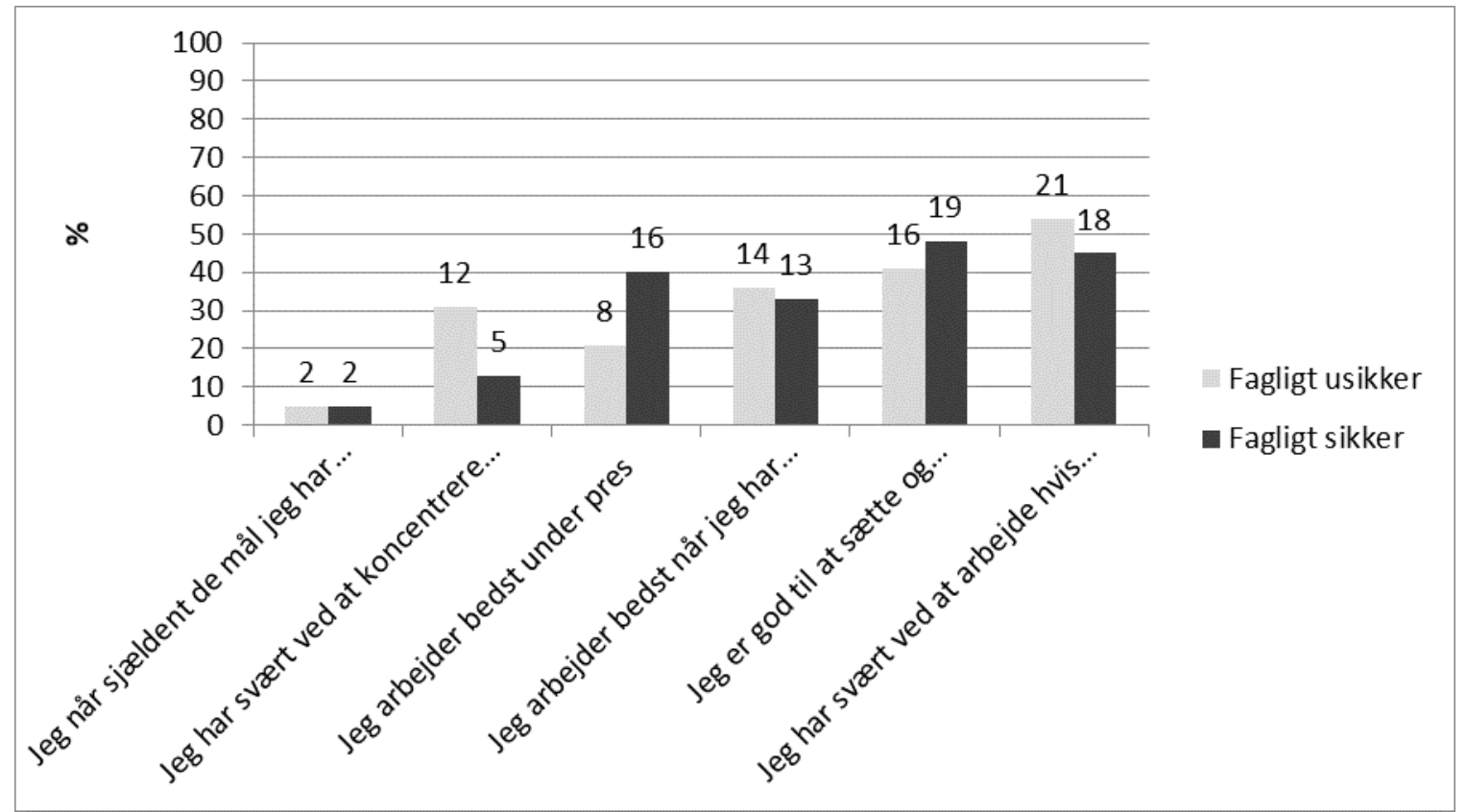

Figur 1. Andel af studerende der tilskriver sig hver af de seks arbejdskarakteristikker. Tallene over hver søjle angiver antallet af respondenter ud af 39/40 der erklærer sig enige i udsagnet.

To af forskellene mellem de to gruppers arbejdskarakteristik er signifikante, nemlig "jeg har svært ved at koncentrere mig i længere tid ad gangen" og "jeg arbejder bedst under pres". Man kan se en tendens i den forventede retning, nemlig at de relativt utrygge studerende $\mathrm{i}$ højere grad er "humørpårvirkelige", altså i højere grad mener at de er afhængige af at være inspirerede, har sværere ved at koncentrere sig i længere tid og overholde deres deadlines. Det er interessant at det er de fagligt sikre som i højere grad (mener at de) arbejder bedst under pres.

\section{Valg af vejleder}

Under overskriften "valg af vejleder" spurgte vi til hvilket kendskab studerende havde til deres vejleder før de underskrev specialekontrakt. Vi spurgte desuden til deres årsag til at vælge den vejleder de havde valgt (hvis de altså selv havde valgt vejleder).

\section{Kendskab til vejleder}

$80 \%$ (63 ud af 79) kendte deres vejleder i forvejen, og alle disse har svaret at de kender deres vejleder "fra undervisning eller vejledning". Derudover har 3 svaret at de kender vejlederen "af omdømme (fx anbefaling fra andre)" og 3 andre at de har "læst vejlederens faglige profil". Der er ingen sammenhæng mellem faglig sikkerhed og kendskab til vejlederen. Man kunne måske forestille sig at dem der havde negative erfaringer fra tidligere vejledning, gjorde andet for at få kendskab til deres kommende vejleder, men der er altså ingen effekt af denne faktor. Det er 4 respondenter med relativt positive og 2 med relativt negative vejledningserfaringer der har opsøgt information af andre veje end gennem undervisning og vejledning. Der synes altså ikke at være nogen klar sammenhæng. 
Årsag til valg af vejleder

Af 79 deltagere har 61 selv valgt eller haft indflydelse på valget af deres vejleder. Der ser ud til at være en svag tendens til at det i højere grad er de fagligt usikre der ikke selv har haft mulighed for at vælge vejleder. Omvendt er der ingen sammenhæng mellem om man selv har valgt vejleder og spørgsmålet om "hvordan har du det med at skulle skrive speciale?". Det ser altså ikke ud til i sig selv at føre til større usikkerhed at vejlederen er udpeget af andre.

Vi spørger dernæst til årsagen til valg af vejleder. Man kunne forestille sig at de fagligt mere usikre ville vælge efter andre kriterier end de fagligt sikre, $\mathrm{fx}$ at de ville fokusere mere på personlighed og mindre på faglighed (se tabel 10). Der er der intet der tyder på er tilfældet.

Tabel 10. Årsager til valg af vejleder sammenholdt med sikkerhedsscore

\begin{tabular}{lllll}
\hline & \multicolumn{3}{l}{ Hvad er det primære grundlag for dit valg af vejleder? } \\
Sikkerhedsscore & Ikke selv valgt vejleder & Faglighed & Personlighed & Total \\
\hline Fagligt usikker & $26 \%$ & $39 \%$ & $36 \%$ & 39 \\
Fagligt sikker & $20 \%$ & $43 \%$ & $38 \%$ & 40 \\
\hline Total & 18 & 32 & 29 & 79 \\
\hline \hline
\end{tabular}

Fra tidligere studier ville vi forvente at studerende fokuserer på vejleders personlighed snarere end på fagligheden (Wichmann-Hansen, Eika \& Mørcke 2007; Andersen \& Jensen 2007; De Kleijn et al. 2012). Det ser imidlertid ikke ud til at være tilfældet. Omtrent lige mange respondenter nævner vejlederens faglighed og vejlederens personlighed, så det er - i hvert fald i de studerendes selvforståelse - e i lige så høj grad faglige overvejelser der ligger til grund for valget af vejleder.

\section{Vejlederrollen og vejlederpersonen}

I denne sektion undersøger vi som sagt ønsker til vejlederrollen og vejlederen som person. Vi ønsker at finde ud af hvilke funktioner specialeskrivere søger hos deres vejleder, hvilke træk der er efterspurgt i en vejleder, og desuden undersøger vi ønsker til rammesætningen af samspillet mellem vejleder og specialeskriver.

\section{Forventningsafstemning}

Vi spørger i spørgsmål 22-24 om ønsket om indledende faste aftaler om henholdsvis specialets indhold, arbejdsprocessen og hinanden. Det gentager fundet fra tidlige studier at et succesfuldt vejledningsforløb især sikres via klare aftaler og forventningsafstemning. Vi finder en overordentlig høj grad af tilslutning til denne forventningsafstemning (se figur 2). Der er en svag men statistisk signifikant tendens til at de fagligt usikre i højere grad ønsker forventningsafstemning på de to punkter "arbejdsproces" og "indhold", mens forskellen er knapt signifikant (chi $\left.{ }^{2}, p=0,06\right)$ på spørgsmålet om "forventninger til hinanden". 


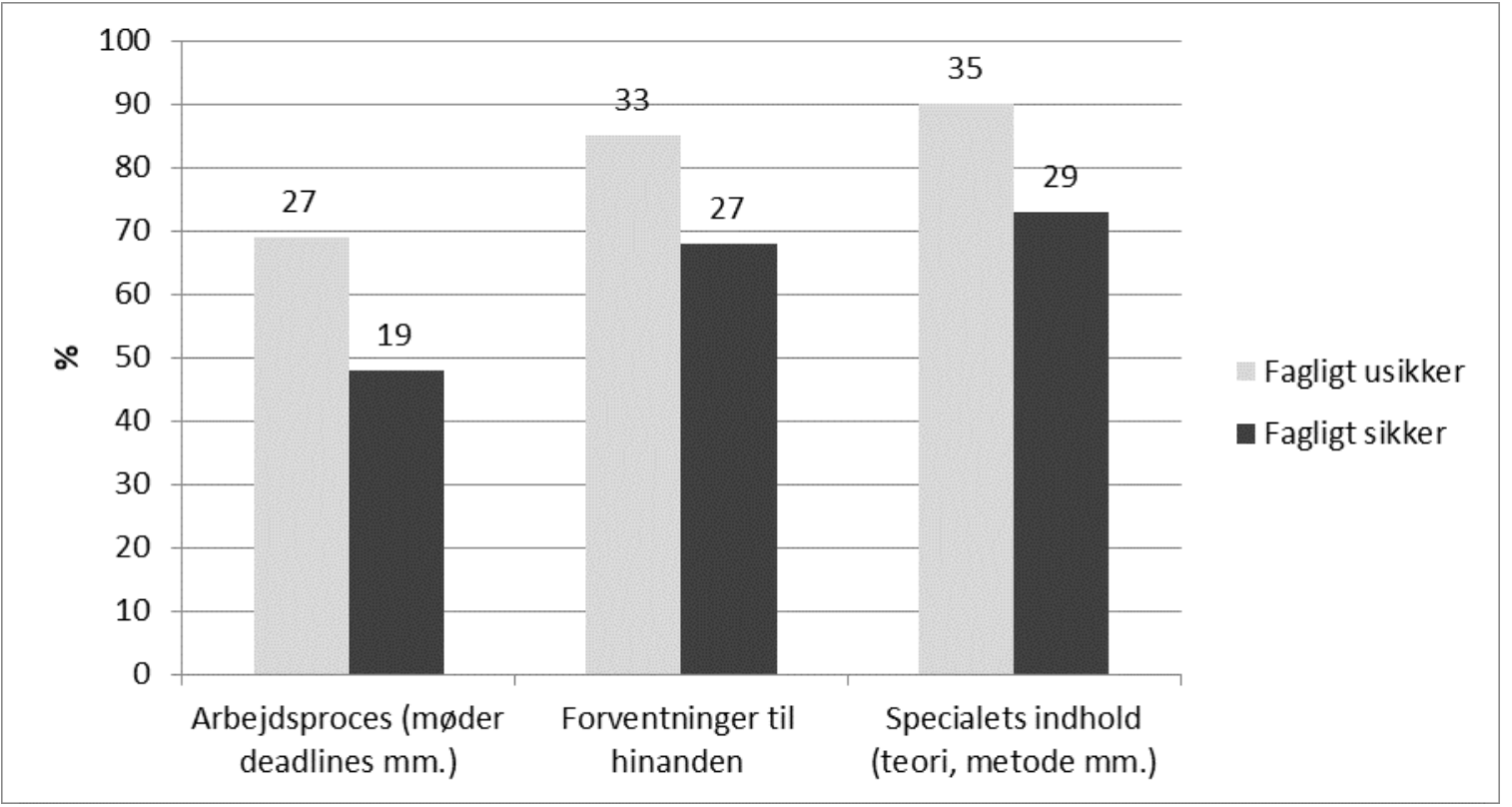

Figur 2. Ønsker til forventningsafstemning opdelt på faglig sikkerhed. Tallene over hver søjle angiver antallet af respondenter ud af 39/40 der erklærer sig enige i udsagnet.

Der er desuden en klar tendens til at det især er specialets indhold der ønskes aftaler om, og i mindre grad arbejdsprocessen.

\section{Forventninger til vejlederhjoelp}

I spørgsmål 25 spørger vi om hvad man især har brug for vejleders hjælp til - og dermed indirekte hvilken rolle man ser vejleder have i specialeskrivningen. Spørgsmålene minder i høj grad om spørgsmålene i Wichmann-Hansen \& Jensens (2013: 335) "forventningsskema". Svarene viser nogle ret store forskelle mellem sikre og usikre specialeskrivere; de viser desuden forskelle i prioriteringen af de forskellige vejlederroller (se figur 3). Respondenterne kunne vælge op til to svar, og vi oplister her valgene efter hyppighed.

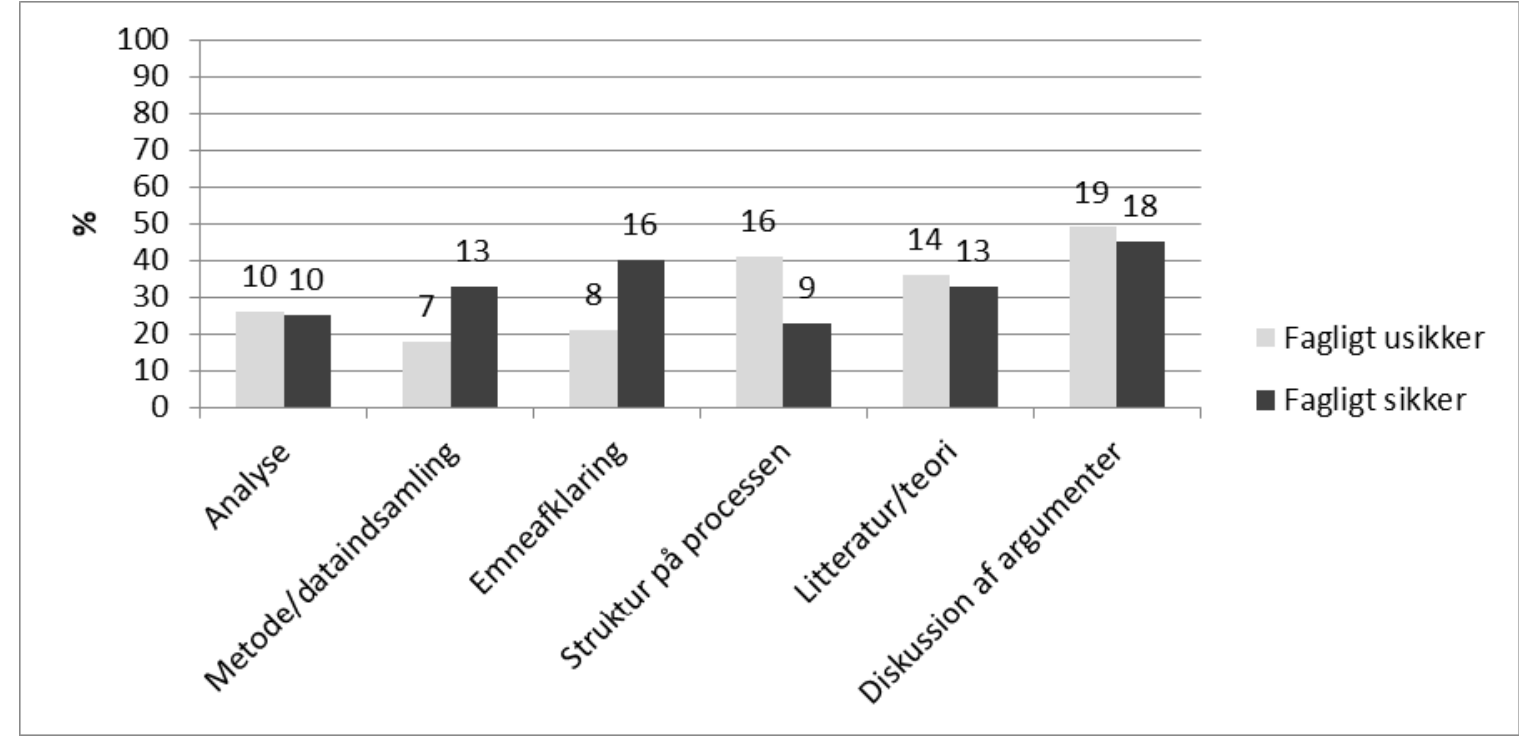

Figur 3. Hvad ønsker man især vejleders hjælp til. Tallene over hver søjle angiver antallet af respondenter ud af 39/40 der erklærer sig enige i udsagnet. 
Overordnet set ønsker man især en vejleder der kan hjælpe med diskussion af "overordnede argumenter" og med "teori", i mindre grad hjælp til "analyse" og "dataindsamling". Der er dog som sagt store forskelle på grupperne. Blandt de usikre er det især afklaring af de store linjer som "diskussion af argumenter" og "struktur på processen" der ønskes vejlederhjælp til, i meget mindre omfang "emneafklaring" og "dataindsamling". Blandt de sikre er det især "diskussion af argumenter" og "emneafklaring", mens "struktur på processen" fylder mindre. Forskellene er særligt tydelige på "emneafklaring" hvor forskellen er signifikant, og på "retning og struktur på processen" som er knapt signifikant (chi $\left.{ }^{2} p=0,06\right)$. Det er de usikre der $\mathrm{i}$ højere grad ønsker hjælp til struktur på processen (måske i overensstemmelse med at de i højere grad ønsker indledende forventningsafstemning).

\section{Vejlederegenskaber}

I spørgsmål 34 nævnes en mængde (19) forskellige karaktertræk ved en (god) vejleder. Indledende havde vi tænkt at karakteristikkerne kunne inddeles efter en overordnet dimension om hvem der har ejerskab og styring over processen i stil med de begrebspar der blev præsenteret i indledningen, fx Gatfields (2005) 'structure' vs. 'support'; eller sagt på en anden måde i hvor høj grad studerende ønsker en vejleder som udstikker en retning for specialet, og i hvor høj grad de ønsker en vejleder som lader dem finde deres egen retning. Vi tænkte at karakteristika som "kritisk" og "struktureret" pegede i den ene retning og "åben over for mine ideer" og "opmuntrende" pegede i den anden (se figur 4). Det er ret tydeligt at karakteristikaene ikke er blevet forstået i forhold til disse dimensioner. Hvis det var tilfældet, ville vi forvente at se at bedømmelser af karakteristika korrelerede i høj grad, nogle positivt (nemlig dem der beskriver den samme type) andre negativt (nemlig dem der tilhører forskellige typer). Vi testede denne hypotese med en Principal Components-analyse, men fandt ingen indikationer af hverken en 1-, 2- eller 3-dimensionel model.

Der er stor forskel på enigheden i de forskellige karakteristika. Ingen ønsker en "kontrollerende" vejleder, og ganske få en "abstrakt tænkende" vejleder der "får mange ideer". Der er især ønske om en "opmuntrende" vejleder der "kan give specialet retning", og det gælder både blandt de sikre og de usikre studerende. De sikre studerende ønsker især en "erfaren", "kritisk" og "detaljeorienteret" vejleder der er "åben over for deres ideer"; de usikre ønsker særligt en "forstående", "helhedsorienteret" og "diskuterende" vejleder. Vi ser måske her en tendens til at de fagligt usikre studerende i højere grad ønsker hjælp og støtte til processen, mens de fagligt sikre i højere grad søger det faglige modspil og den faglige udfordring. Det synes at harmonere med svarene i forrige afsnit der viste at usikre studerende søger hjælp til "struktur på processen", mens sikre studerende søger hjælp til "emneafklaring" og "dataindsamling". 


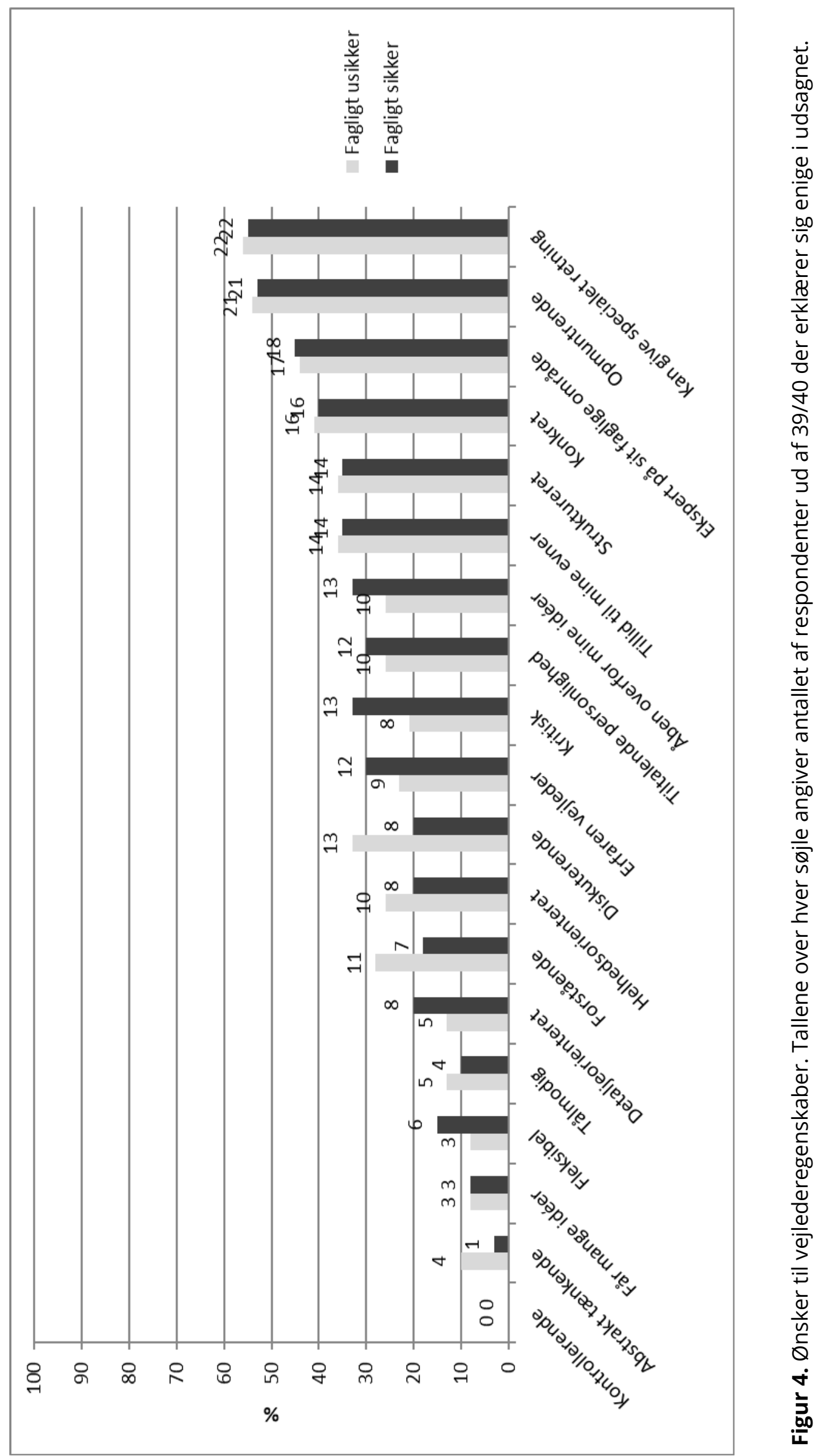




\section{Opsummerende om vejlederen}

Som en opsummering af ønsker til vejlederen stillede vi et spørgsmål om hvorvidt vejleder først og fremmest skal være "ekspert inden for mit specialeområde" eller "en guide i specialeprocessen". Man kan mene det gentager spørgsmålet om vejlederkarakteristika, først og fremmest modsætningen mellem vejlederen som "opmuntrende" og "retningsgivende" osv. vs. "faglig ekspert".

Tabel 11. Svar på spørgsmålet "en vejleder skal først og fremmest være..." sammenholdt med sikkerhedsscore

En vejleder skal først og fremmest være:

\begin{tabular}{lrrr} 
Sikkerhedsscore & Ekspert inden for mit specialeområde & En guide i specialeprocessen & Total \\
\hline Fagligt usikker & $21 \%$ & $80 \%$ & 39 \\
Fagligt sikker & $23 \%$ & $78 \%$ & 40 \\
\hline Total & 17 & 62 & 79 \\
\hline \hline
\end{tabular}

Resultatet er som ovenfor et "både-og"-svar, men hvor de fleste, både af de fagligt sikre og de fagligt usikre, mener at vejlederen først og fremmest skal være en guide i specialeprocessen. Det gentager hvad der tidligere er fundet (Wichmann-Hansen, Eika \& Mørcke 2007: 15; Andersen \& Jensen 2007), nemlig at universitetet fokuserer på vejlederens faglige kvaliteter, mens studerende oftere fokuserer på interpersonelle kvaliteter. Vores ide om at denne præference skulle være under forandring er altså gjort til skamme.

\section{Diskussion og konklusion}

På trods af den store faglige lighed er det en divers flok med meget forskellige ønsker der er blevet spurgt. På et overordnet plan er det interessant at se forventninger til arbejdsindsats og karakter: Respondenterne forventer i gennemsnit et 10-tal og forventer typisk at lægge omkring 20-30 timer i arbejdet.

Mest overraskende er det måske at se hvor stor en andel af respondenterne der udpeger "særlige forhold" som vil besværliggøre deres specialeskrivning, stress, depression, sygdom etc. Det er i sig selv bekymrende at så mange føler sig udsatte, og det kalder på videre studier. For vejledningsprocessen er det yderligere påfaldende at disse særlige forhold ikke fører til lavere forventninger til resultatet i form af karakter. Det er oplagt et emne der giver anledning til en forventningsafstemning vejleder og studerende imellem.

Specialeskrivere vælger især vejledere de kender i forvejen, og de ønsker især en vejleder der støtter og opmuntrer, som kan hjælpe med at give specialet form, og som kan være faglig garant for kvaliteten. Vejleder skal især hjælpe med de store linjer i specialet, emneafklaring, tilpasning af argumenter og valg af teori.

Især i forbindelse med de sidste er der forskel på det vi har kaldt "de fagligt sikre" og "de fagligt usikre" specialeskrivere. De fagligt sikre ønsker i højere grad en faglig ekspert som medog modspiller, mens de fagligt usikre i lidt højere grad ønsker en vejleder der kan guide og støtte. 
De fagligt usikre specialeskrivere er desuden karakteriseret ved at de i højere grad ønsker faste aftaler og forventningsafstemning tidligt i forløbet, især om specialets indhold. Det så vi bl.a. afspejlet i spørgsmålet om hvad der skal lægges faste aftaler om fra start af forløbet. I litteraturen (Wichman-Hansen \& Jensen 2013, Laustsen et al. 2012) anbefaler man især klare linjer om rammerne for vejledningen: hvordan foregår feedback, hvordan kontakter man hinanden osv. Vi har funderet over om det kan ses som et udtryk for at de i højere grad er i tvivl om hvilke forventninger der stilles til dem, og hvad et speciale skal indeholde. Dette resultat spiller interessant ind i diskussionen af vejleder som "procesvejleder" eller "faglig ekspert" og i en vis forstand specialet som læringsproces kontra specialet som produkt. Når de fagligt usikre i højere grad ønsker "struktur på processen", kan det måske tages som et tegn på at de ønsker at vejlederen lægger rammer og klarlægger hvad de skal gøre - altså det vi beskrev som en vejleder med en højere grad af 'control' (De Kleijn et al. 2019) eller 'structure' (Gatfield 2005). Omvendt kunne man et stykke henad vejen sige det samme om de sikre studerende der søger hjælp til "dataindsamling" og "emneafklaring". Når man sammenholder resultatet her med resultaterne nedenfor, synes det dog at være andre funktioner de to grupper søger i deres vejleder.

Derudover fandt vi en tendens til forskellige arbejdsformer hos fagligt sikre og usikre. Noget tyder på at fagligt sikre i højere grad er trænede i og bekvemme med at være under tidspres fordi de tilsyneladende ved at det ikke er en holdbar strategi kun at arbejde/skrive når man er "indre-motiveret". Det virker dermed relevant at tage hensigtsmæssige arbejdsformer op som et emne i vejledningen, både for at sikre et bedre produkt, for at styrke gode vaner til det efterfølgende arbejdsliv og som en hjælp til de mange specialeskrivere der føler sig mentalt og tidsmæssigt presset bl.a. som konsekvens af fremdriftsreformen. Vi overvejer desuden om der på institutter bør være et tilbud til alle nystartede specialestuderende om projekt- og tidsstyring, planlægning af skriveprocessen osv. Undersøgelsen viser at fagligt usikre studerende i højere grad (tror at de) er afhængige af at være motiverede for at kunne skrive, mens skriveforskningen viser at skriveproduktion i højere grad er et spørgsmål om at indarbejde sikre og systematiske skrivevaner. Det kunne formentlig være nyttigt for de usikre studerende at lære dette. Omvendt kan man fremhæve at opbygning af sunde (studie)vaner er en væsentlig del af alle rusforløb og de vigtigste skrivehåndbøger (fx Rienecker \& Jørgensen 2006), og hvis de fagligt usikre specialeskrivere ikke har lært dem endnu, skal der formentlig mere til end et kort skrivekursus - fx en løbende forventningsafstemning med en vejleder.

Ellers er det mest påfaldende måske hvor små forskelle der generelt er mellem de "fagligt sikre" og de "fagligt usikre" studerende. De går i al væsentlighed til specialearbejdet med de samme forventninger til resultat og arbejdsindsats, og de har lignende ønsker til deres vejleder. Det kan måske skyldes vores operationalisering af "sikre" og "usikre" som en kombination af BA-karakter og (selvrapporterede) erfaringer med vejledning og (u)sikkerhed ved at skulle skrive speciale. Vi finder en vis støtte for inddelingen i at de tre mål korrelerer i nogen grad, men en rimelig indvending ville være at det ikke er fornuftigt med en 2-niveauinddeling der deler respondenterne 50-50, men at vi fx skulle have fokuseret på de 20 \% mest usikre.

Overordnet får vi igen bekræftet vigtigheden af den personlige relation i vejledningen og af vigtigheden af forventningsafstemning i løbet af vejledningsprocessen. Vi har således vist at 
forskellige studerende har forskellige baggrunde, erfaringer, forventninger (bekymringer) og ønsker både til deres specialeskrivningsproces og til deres vejleders person og hendes relation til dem. Vejlederen kan således ikke tage mange forventninger for givet, og det er derfor oplagt at vejleder og vejledt må diskutere disse forhold for at opnå et vellykket forløb.

Vi har ikke som fx Laustsen et al. (2012) eksplicit undersøgt hvordan man ønsker at forventningsafstemningen skal finde sted - fx i form af et såkaldt vejlederbrev som de foreslår men vi mener at vores resultater lægger op til at man som vejleder skal være forsigtig med at tro at studerendes behov og ønsker er ens. Fordi studerendes erfaringer og forventninger er forskellige, er det oplagt at forestille sig at de vil læse det samme vejlederbrev forskelligt og få forskelligt ud af det. Vores anbefaling er derfor at man gør forventningsafstemningen til en løbende proces og et tilbagevendende emne i vejledningen. Et vejlederbrev som beskrevet af Wichman-Hansen \& Jensen (2013) og Laustsen et al. (2012) er et redskab hvor vejlederen i høj grad beslutter hvad der er vigtigt at tale om som en del af forventningsafstemningen. Vi mener at vores resultater har vist at der kan være behov for også at bruge andre mere åbne dialogiske metoder hvor de studerende kan få mere indflydelse på hvad skal tales om og laves aftaler omkring.

På baggrund af vores resultater mener vi at det er relevant for vejlederen at spørge de studerende om deres forventninger til at skulle skrive speciale, herunder deres følelser, bekymringer og tidligere erfaringer - altså det vi forsøger at samle under overskriften "faglig sikkerhed". Vi vil anbefale forsigtighed med at spørge direkte til hvilken karakter nystartede specialestuderende fik for deres BA-opgave. Studerede kan føles sig sat i bås, og der kan være mange gode grunde til at et BA-projekt ikke endte så godt som det kunne. Omvendt er vi også bekymrede for at studerende starter på specialeskrivningsarbejdet med urealistisk høje forventninger til hvilken specialekarakter de kan (og vil) opnå. Det kan, er vi sikre på, føre til både stor skuffelse og øget mentalt pres. Samlet set vil vi på ingen måde sige at tidligere karakterer og erfaringer med vejledning skal træde i stedet for den personlige forventningsafstemning, men blot at det kan være elementer der kan indgå i en sådan afstemning.

\section{Referencer}

Andersen, H. L. \& Jensen, T. W (2007). Specialevejledning - rammer og roller. Frederiksberg: Samfundslitteratur.

Anderson, C., Day, K. \& McLaughlin, P. (2008). Student perspectives on the dissertation process in a Master's degree concerned with professional practice. Studies in Continuing Education 30(1), 33-49.

Cohen J. (1988). Statistical power analysis for the behavioral sciences, 2nd ed. Hillsdale N.J: Lawrence Erlbaum.

Danske Universiteter (2017). Tal om de danske universiteter 2017. url: https://dkuni.dk/wpcontent/uploads/2018/04/du_tal_om_danske_universiteter_2017.pdf (hentet 15. januar 2019). 
Demb, A. \& Funk, K. (1999). What do they master? Perceived benefits of the master's thesis experience. NACADA Journal 19(2), 18-27.

Eurostat (2018). Tertiary education statistics. url: https://ec.europa.eu/eurostat/statisticsexplained/index.php?title=Tertiary_education_statistics (hentet 15. januar 2019).

Field, A. (2014). Discovering statistics using IBM SPSS statistics, $4^{\text {th }}$ ed. London: Sage.

Van Gennep, A. (1909 [1960]). The rites of passage. London: Routledge.

Gatfield, T. (2005). An investigation into PhD supervisory management styles: development of a dynamic conceptual model and its managerial implications. Journal of Higher Education Policy and Management 27(3), 311-325.

Grant, B.M. (2005). Fighting for space in supervision: fantasies, fairytales, fictions and fallacies, International journal of qualitative studies in education 18(3), 337-354.

Greenbank, P. \& Penketh, C. (2009). Student autonomy and reflections on researching and writing the undergraduate dissertation, Journal of Further and Higher Education 33(4), 463-472.

Handal, P. \& Lauvås, G (1997). Vejledning \& praktisk fagteori. Århus: Klim.

Handal, P. \& Lauvås, G (1998). Hovedfagsveiledning ved Universitetet i Oslo. Universitetet i Oslo, Fagområdet for universitetspedagogikk.

Handal, G., \& Lauvås, P. (2007). Veiledning i de videregående utdannelser. Dansk Universitetspcedagogisk Tidsskrift, 2(3), 4-10. Hentet fra https://tidsskrift.dk/dut/article/view/5635.

Kvale, S. \& Brinkmann. S. (2015). Interview, 3. udg. København: Hans Reitzel.

Lauridsen, L.K (2006): Forventninger kontra fakta. Universitetsavisen 7. december 2006. Hentet fra https://universitetsavisen.ku.dk/dokument9/nyhedsarkiv/2006/2006-12/061207j/

Laustsen. S., Wichmann-Hansen, G., Aagaard, H,Bahrami, G. \& Dreyer, P. (2012) Brugen af vejlederbrev til universitetsstuderende - en diskussion af dets betydning i vejledningsprocessen. Dansk Universitetspoedagogisk Tidsskrift, 7(12), 46-57. Hentet fra https://tidsskrift.dk/dut/article/view/5854/5340.

Harboe, T. \& von Müllen, R. (2006). De studerendes forventninger til specialevejledningen, en spørgeskemaundersøgelse på Det Samfundsvidenskabelige Fakultet og Det Juridiske Fakultet, Københavns Universitet. Købehavns Universitet, Pædagogisk Center for Samfundsvidenskab.

Jensen, H. N. (1992). Specialevejledning - resultater af en undersøgelse blandt vejledere og vejledte. København: Københavns Universitet, Institut for Statskundskab.

Jensen, H. N. \& Christensen, N. (2012). Dialogisk specialevejledning - sammenfattende rapport om projektforløb og resultater. Københavns Universitet,Det Samfundsvidenskabelige Fakultet.

Kleijn, R. A. M. de, Mainhard, M. T., Meijer, P. C., Pilot, A. \& Brekelsmans, M. (2012). Master's thesis supervision: relations between perceptions of the supervisor-student relationship, final grade, perceived supervisor contribution and student satisfaction. Studies in Higher Educations 37(8), 925-939. 
Mainhard, T, van der Rijst, R., van Tartwijk, J. \& Wubbels, T. (2009). A model for the supervisordoctoral student relationship. Higher Education58, 359-373.

Murphy, N., Bain, J. D. \& Conrad, L. M. (2007). Orientation to the research higher degree supervision. Higher Education 53(2), 209-234.

Rienecker, L., Harboe, T. \& Jørgensen, P. S. (2005). Vejledning - en brugsbog for opgave- og specialevejledere på videregående uddannelser. Frederiksberg: Samfundslitteratur.

Rienecker, L. \& Jørgensen, P. S. (2006). Den gode opgave, 3. udg., Frederiksberg: Samfundslitteratur.

Tofteskov, J. (1996). Projektvejledning -og organisering af projektarbejde. Frederiksberg: Samfundslitteratur.

Universitetsavisen (2019). Kritik: Nye specialefrister udhuler specialet og stresser studerende. Hentet fra https://uniavisen.dk/kritik-nye-specialefrister-udhuler-specialet-ogstresser-studerende/

Wichmann-Hansen, G., Eika, B., \& Mørcke, A. M. (2007). Hvad findes der af litteratur om vejledning? - Litteratursøgning med fokus på publicerede, evidensbaserede studier. Dansk Universitetspoedagogisk Tidsskrift, 2(3), 11-19. Hentet fra https://tidsskrift.dk/dut/article/view/5636.

Wichmann-Hansen, G. \& Jensen, T. W. (2013). Processtyring og kommunikation i vejledning. In: Rienecker, L., Jørgensen, P. S., Dollin, J., \& Ingerslev, G. M. (eds.), Universitetspcedagogik (329-350). Frederiksberg: Samfundslitteratur. 


\section{Appendiks: Spørgeskema}

\section{Dine forventninger til specialevejledningen}

Tak fordi du tager dig tid til at udfylde dette spørgeskema.

Denne undersøgelse har til formål at belyse de studerendes forventninger til specialevejledningen.

Spørgsmålene omhandler både personlige forhold og erfaringer i relation til specialeprocessen

samt forventninger til vejleder.

Besvarelsen tager 5-10 minutter at gennemføre og er anonym.

Hvis du har spørgsmål til undersøgelsen, kan du skrive til: jthoegersen@hum.ku.dk

Første del handler om personlige forhold og forventninger

omkring specialeprocessen

\section{Hvad studerer du?}

2. Alder

3. Køn

Kvinde

Mand

Andet:

4. Hvordan har du det med at skrive speciale?

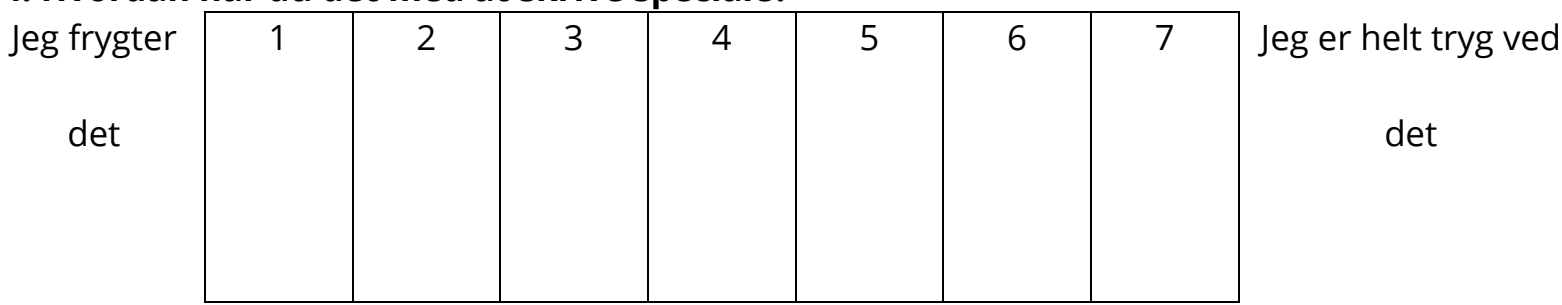

\section{Hvilken karakter forventer du at få for dit speciale?}

$\begin{aligned}- & 00 \\ - & 2 \\ - & 4 \\ - & 7 \\ - & 10 \\ - & 12\end{aligned}$

6. Har du planer om en ansættelse ved et universitet (ph.d.)?

_ Ja

Nej 


\section{Arbejdsform}

7. Hvilke karakteristikker passer bedst på din måde at arbejde på? (Vælg 1-2)

Jeg har svært ved at koncentrere mig i længere tid ad gangen

Jeg når sjældent de mål, jeg har sat mig for

Jeg er god til at sætte og overholde deadlines

Jeg arbejder bedst, når jeg har god tid

Jeg har svært ved at arbejde, hvis jeg ikke er inspireret eller motiveret

Jeg arbejder bedst under pres

8. Hvor mange timer om ugen regner du realistisk set med at arbejde på specialet?

9. Har du arbejde ved siden af?

Ja

Nej Spring til spm. 11

10.Hvor mange timer? (kun stillet hvis man har svaret "ja" til spm. 9)

11. Er der personlige forhold, der kan indvirke på din arbejdsevne (såsom psykiske udfordringer, privatliv eller fysisk funktionsnedsættelse)?

Ja Nej Spring til spm. 13

12. Beskriv gerne: (kun stillet hvis man har svaret "ja" til spm. 11)

13. Hvilken karakter fik du for dit BA-projekt?

2
-4
-7
-10
-12

De næste spørgsmål handler om din erfaring med vejledning og dine forventninger til nuværende eller kommende vejledning

14. Hvad er din tidligere erfaring med vejledning?

Meget posi-

tiv

\begin{tabular}{|l|l|l|l|l|}
\hline 1 & 2 & 3 & 4 & 5 \\
& & & & \\
\hline
\end{tabular}

Meget nega-

tiv

15. Uddyb gerne: 
16. Har du en vejleder på nuværende tidspunkt?

- Ja

Nej Spring til spm. 22

17.Hvor mange vejledningsmøder har I haft? (kun stillet hvis man har svaret "ja" til spm. 16)

18. Kendte du din specialevejleder i forvejen? (kun stillet hvis man har svaret "ja" til spm. 16)

- Ja

_ Nej Spring til spm. 20.

19. Hvor kender du hende/ham fra? (kun stillet hvis man har svaret "ja" til spm. 18)

__ Af omdømme ( $\mathrm{fx}$ anbefaling fra andre studerende)

_ Fra undervisning eller vejledning

_ Har læst hendes/hans faglige profil Andet:

20. Har du selv valgt din vejleder eller haft indflydelse på valget? (kun stillet hvis man har svaret "ja" til spm. 16)

- Ja

Nej Spring til spm. 22.

21. Hvad er det primære grundlag for dit valg af vejleder? (kun stillet hvis man har svaret "ja" til spm. 20)

_ Personlighed

_ Faglighed

Er det vigtigt for dig, at du og din vejleder laver klare aftaler fra starten om:

22. Arbejdsproces (møder, deadlines, antal sider til aflevering o.I.)

- Ja

- Nej

23. Specialets indhold og form (teori, metode, analyse o.I.)

- Ja Nej

24. Forventninger til hinanden (hvad forventer du af vejleder, og hvad forventer vejleder af

dig)

- Ja

- Nej

25. Hvad har du mest brug for, at din vejleder hjælper dig med? (Vælg op til 2)

Emneafklaring

Litteratur/teori

Metode og empiri/dataindsamling

Analyse

Diskussion af specialets argument(er)

_ Retning og struktur på specialeprocessen 
Andet:

26. Skal vejleder godkende det endelige speciale før aflevering?

- Ja

$\mathrm{Nej}$

27. Hvor længe forventer du, et gennemsnitligt vejledningsmøde vil tage?

20-30 min

- 30-45 min

- 45 min - 1 time

- $1-11 / 2$ time

- $11 / 2-2$ timer

28.Skal vejleder være tilgængelig mellem vejledningsmøderne (via mail eller telefon)?

- Ja

_ Nej Spring til spm. 30.

29. Hvor lang tid bør der maksimalt gå, før vejleder svarer på en henvendelse fra dig? (kun stillet hvis man har svaret "ja" til spm. 28)

3 timer

- 1 dag

- 2 dage

4 dage

- 1 uge

- 2 uger

30. Skal vejleder tage kontakt til dig, hvis det er lang tid siden jeres sidste kontakt? * - Ja

- Nej

De næste spørgsmål handler om vejleders rolle og egenskaber

31. Hvilken rolle foretrækker du fra din vejleder?

_ Min vejleder skal lade mig arbejde frit uden for mange krav

_ Min vejleder skal stille krav og give mig konkrete opgaver

32. Betyder det noget for dig, om du kan tale med din vejleder om personlige forhold?

- Ja

Nej

33. Betyder det noget for dig, om der er plads til small-talk mellem dig og din vejleder (fx

om fritid og fælles interesser)?

- Ja Nej

34. Hvilke egenskaber foretrækker du først og fremmest hos din vejleder? (Vælg de 5, der passer bedst)

_ Åben overfor mine idéer 
Forstående

_ Tålmodig

Fleksibel

Tillid til mine evner

Struktureret

Erfaren vejleder

Helhedsorienteret

- Opmuntrende

Kontrollerende

_ Ekspert på sit faglige område

_ Detaljeorienteret

Kritisk

Konkret

_ Tiltalende personlighed

Diskuterende

_ Abstrakt tænkende

_ Kan give specialet retning

_ Får mange idéer

35. En vejleder skal først og fremmest være:

Ekspert inden for mit specialeområde

__ En guide i specialeprocessen

36. Hvor meget tror du, vejleder betyder for resultatet af det endelige speciale?

Meget lidt

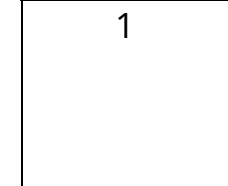

2

3

\begin{tabular}{l|l}
3 & 4
\end{tabular}

(1)

5

Rigtig meget

Tak for besvarelsen

kontakt: jthoegersen@hum.ku.dk 